\title{
Sociocultural Aspects of Transformation \\ of Administrative System in Kizlyar \\ in the Second Half of the Eighteenth and Early Nineteenth Centuries
}

\author{
Mahomed M. Gasanov \\ Daghestan State University \\ Abidat A. Gazieva \\ Daghestan State University
}

\begin{abstract}
This article discusses the transformation of the commandant control system in the city of Kizlyar. The article covers the issues of managing the city from the second half of the $18^{\text {th }}-19^{\text {th }}$ centuries. Depending on the situation in the empire, Caucasian politics as a whole also changed and changed. The article attempts to analyze the meaning and role of the commandant's office in resolving economic, political and administrative issues in the city of Kizlyar. The economic and sociocultural aspects of the commandant's activities are considered in the period under study, since this stage is the key to Caucasian politics. The primary tasks faced by the commandants of the fortress by the middle of the $19^{\text {th }}$ century were the solution of socio-economic problems, cultural and educational work and familiarizing the local population with the Russian legal space. The system of commandant control of the city of Kizlyar was transformed from simple supervision to the solution of the most important for the life of Kizlyar and the Northeast Caucasus as a whole.
\end{abstract}

\section{INTRODUCTION}

In the middle of the eighteenth century, Kizlyar played a key role in the history of the Russian empire, being a 'mini-state' that provided communication between Russia and the Caucasus. Since its foundation, Kizlyar was "“a kind of a capital" in the Caucasus' (Gadzhiev, Davudov, and Shikhsaidov 2004: 432). It was under the supervision of the military governor of Astrakhan and the State Military Council. The region was underpinned by Social Evolution \& History, Vol. 17 No. 1, September 2018 109-120 
the Astrakhan governor and the administration of the province. However, the Kizlyar commandants had a certain degree of independence.

\section{DATA AND METHODS}

The main data on the research topic was collected from open resources: scientific websites, journal publications and periodicals.

Using all the sources at our disposal, concentrating the achievements of the national historical science, we tried to analyze the influence of economic and cultural factors on the transformation of the administrative system in Kizlyar from the second half of the eighteenth century to the end of the Caucasian war. The theoretical and methodological basis for the study relies on the principles of historicism and objectivity. The application of historical methods - historical and comparative, historical and situational, and sociocultural - has allowed a systemic study of historical facts in the context of transformation of administrative and managerial system in Kizlyar during the defined period.

\section{DISCUSSION}

The fortress of Kizlyar on the bank of the Terek was founded by Vasily Yakovlevich Levashev in 1735. Levashov was one of the first Russian military leaders in the Caucasus, the first Russian governor of the Transcaucasus, and the founder of the city of Kizlyar.

As soon as this fortress was ready for comfortable dwelling, all the servicemen from the fortress of Holy Cross left before, were transferred here in October 27, 1735', - he wrote. General Levashev instructed the first commandant of the fortress colonel Krasnogorodtsev 'about proper treatment of highlanders, about amanats, baranta and reprisals (retribution), about Christian captives and people who left mountains to settle with us (Butkov 1869).

The commandants of the Russian fortresses in the north-eastern Caucasus had in their hands absolute military, civil and political power over a fairly large territory. All management of military and civilian agencies in the region was carried out from the fortress of the Holy Cross. The list of instructions reveals that the commandant had a wide range of powers.

The commandant, who was the chief of the military fortress, executed the governmental decrees and orders of the generals of the Nizovoi corps, thus putting into practice the principles and methods of implementation of Russia's Caucasian policy on its subordinate territory. Thus, by the decree of October 2, 1731 the board of Foreign Affairs imposed a duty on the commandant of fortress of Holy Cross Eropkin 'to reconnoiter persistently' whether the Crimean sultan was going to oppress the Ka- 
bardians, revenging them for support from the Russians. 'And if ... anyone from the Crimean side or Kuban will attack Kabarda' it should be defended. 'And in the case of need ... troops and cannons from the fortress of Holy Cross should be sent to Kabarda' for the purpose of its defense (Chekulayev 2008). Following these instructions of the Russian government, the commandant of the fortress would many times send Russian troops to protect Kabarda. Besides, the instructions of Board of Foreign Affairs reveal that the external diplomatic negotiations were also under the authority of commandants of the town of Kizlyar.

The commandants were responsible for the military garrison disposed in the fortress in order to keep peace and order inside and outside it, and to protect the town from the enemy. The financial and political functions were also under commandants' jurisdiction.

In addition to direct commandant's duties around the town and fortress the commandant controlled the relationships with the neighboring owners who accepted Russia's protection, and amanats from 'the mountain peoples', quartered in the fortress of Holy Cross. He was charged to pursue the Caucasian policy of Russia in feudal territories of the NorthEastern Caucasus.

Thus, the commandant of the fortress had quite large powers. He was directly associated with the Foreign Affairs Council, regulated relations between Caucasian feudal lords, monitored salary payments to those who recognized Russian citizenship, maintained contacts with the states and peoples of Transcaucasia and protected the interests of the Russian state in the region (Chekulaev 2008).

From the very beginning of the city, all important political events in the Caucasus related to the development of trade, economy, development of agriculture, serious lawsuits and the relationship between the feudal lords were held with the participation of the Kizlyar administration. The questions of economic, cultural and administrative development of the town were under authority of the commandant of fortress. Kizlyar commandants directly received instructions from Board of Foreign Affairs, but at the same time many issues were solved to their discretion, proceeding from the situation arisen in the region.

Civil management did not exist in the North Caucasus until 1785. All power (military and administrative) was in the hands of military commandants. Nevertheless, due to increasing mutual trust, the Russian and local population drew closer more and more and established relations.

In Kizlyar the power was concentrated in the hands of military as well. In most cases the judicial and civil matters were verbally agreed or as they said 'by speedy trial', and only the most important affairs would be written down. The general judicial authority was in the hands of the Board consisting of three military officers appointed to the position at 
the choice of their comrades. There was a special Asian court for Mohammedans in Kizlyar. Disputes over commercial matters were considered by the merchants themselves.

In 1774, the government ordered the creation of a provincial altar, rather than the previously existing civilian leadership, which was supposed to manage internal, civil and judicial affairs, as well as accusations and congregations. The system of local government and administration in the city, as well as throughout Russia, was formed in the middle of the eighteenth century, when there were city magistrates who performed judicial, administrative, police and tax functions. There were officers close to the commander of Kizlyar, who sorted imported and exported metal money (Gadzhiev 1988: 75).

With the foundation of Kizlyar, there immediately emerged governmental and local agencies along with commandant's management with chancelleries (Garrison office and Civil chancellery). To try cases in both chancelleries there were appointed a judge with the rank of Major and members 'in each separately one lieutenant and sub-lieutenant, with consent choice of both Regimental Staff officers and chief officers'. At the same time both chancelleries did not take any actions without commandant's permission and waited for his instructions in all affairs. Military cases were tried in one of the chancelleries, and civil matters in the other. At the same time, Kizlyar commandants acted as diplomats. On behalf of the Russian government they conducted negotiations with the representatives of foreign states, with the Georgian Tsars, feudal owners of the Caucasus and Transcaucasia. For secret correspondence with the government and with the Russian residents in the neighboring states the commandants had a secret code 'while writing secret letters to the High office and other places' (Butkov 1869).

Under commandant there was established a 'secret expedition' which was like an intelligence service. The Kizlyar commandants received foreign ambassadors passing through Kizlyar to Russia, the Georgian tsars and heirs, with their families and escort. Daghestanian and Kabardian princes and feudals also visited the town in order to give their requests or demands to the Russian government and to settle disputes among themselves. At the same time, the Kizlyar commandants acted as arbiters. The feudals of the North-East Caucasus gave an oath on loyalty to the Russian state. The amanat yard was located there too (Garunova 1999).

The Russian administration in the Caucasus did its best to stop 'human trafficking' so Kizlyar commandant tried to prevent slavery. The commandant was told about slaves who left their owners and went to $\mathrm{Ki}$ zlyar and wanted to be baptized, to find out whether any murder had been committed. Otherwise, they would be sent back. Those who did not 
commit murder were christened, despite the owners' requests and then without permission to live in Kizlyar, to send either to Cossacks or to work in ploughed field at will' (Butkov 1869).

According to A. N. Berzh, before the creation of the province of Caucasus, headed by the governor in Ekaterinograd, Russian positions on the Terek, from the Caspian Sea to the Azov Sea, were under the influence of the commandant of Kizlyar, who were considered the highest governance structure in the Caucasus.

Kizlyar was the 'capital' of the multinational Caucasus region, although in administrative terms it was still subordinated to other capitals. By the end of the nineteenth century, the city expanded and turned from a fortress, protecting the territory, into a strategically important city in economic, cultural and educational terms. For many years, the city of Kizlyar remained a true center of political, economic and cultural life in the Caucasus. It fulfilled the major task of protecting the South of Russia from the views of Iran and Turkey and rendering assistance to the Russian and local peoples.

The role and value of the most commandants' management also increased from year to year. None of the city-life events escaped the close attention of the commandant as a chief representative of a city control system. One can argue that the commandants' management in the city evolved by the end of the eighteenth century - from simple military supervision and control to the solution of the administrative-territorial problems and economic development, without forgetting also about the direct duties - the protection of the southern borders of the Russian Empire.

In 1783, the Treaty of St. George Trakeea was concluded, and Georgia joined Russia. In the same year, the Georgian military road was built through the mountains and canyons by the selfless work of Russian soldiers. So the cities Georgiyevsk, Ekaterinograd, Vladikavkaz and Mozdok started to play an even more important role in the Russian strategy in the Caucasus while Kizlyar transferred them a role of political and cultural center. Since that time the Kizlyar administration exerted no decisive impact on the adoption of major political decisions concerning the Caucasus since the governor was the most influential person in the Caucasus. In the last quarter of the eighteenth century, Kizlyar gradually disappeared in the background, giving way to cities that became centers of economic and cultural life in the region.

The importance of the Kizlyar city administration increases in the first quarter of the nineteenth century in connection with the Caucasian war since its economic, administrative, political and cultural meaning grew in the course of military operations. Kizlyar became a link between highlanders and representatives of tsarist administration. At this period the situation in the region brought the tsarist administration to the deci- 
sion to improve the administrative system of the city since it became the center of economic and cultural and educational development.

Due to the economic development of the city and constant influx of migrant workers from June 1, 1841, a position of trustee over the mountaineers was created in Kizlyar. The Russians tried to influence the minds of the local population via trade and other economic mechanisms. The bureaucratic apparatus expanded while the military management was preserved. In 1842 the board of guardians on coming highlanders was entrusted to staff an officer corps of gendarmes of the town. From archival documents it is clear that the post of the guardian '... had small power ...' (People's Liberation Fight ... 2005: 252) and had to be only their patron. In 1843 an instruction was issued to the trustee over the peaceful mountaineers on how to behave and strictly differentiate their competencies.

The trustee had to control the peaceful highlanders and had an opportunity to sell and buy their goods in the markets. In addition, he was responsible to supervise '...there was no highlander in the town without a ticket allowing him to reside in Kizlyar' (People's Liberation Fight... 2005: 271). Without the trustee's written permission the highlanders could neither enter the town, nor leave it. Such strict restrictions were introduced for several reasons. Firstly, it was a necessary measure in time of war to eliminate spies and informers, and secondly, it was possible to regulate the work of industrial institutions since an unauthorized leaving a workplace could undermine the rates of economic development of the enterprises. The trustee's work on taxation gave profit to the town.

If the trustee failed to collect taxes in favor of the town (25 silver kopecks per a person) (Ibid.: 271) he would be fined. All the activity of the trustee had to inspire peaceable disposition and diligence in highlanders, and also to bring them under the Russian laws.

The handicraft industry was rapidly developed in Kizlyar in the period under study, which, according to tsarist administration, '... implanted peace habits in rebellious tribes' (Ibid.: 236). The royal administration was aware of the importance of trade with the mountaineers. In particular, in 1818 Alexey Yermolov wrote to Count Guriev: 'Trade is the only way to get closer to mountain people ...' (Velikaya 2012a: 48). According to Alexander I's decree of July 6, 1810, which was aimed at bringing the highlanders to trade with Russia, 'The commander unfolds barter with the highlanders along the whole Caucasian line' (Idem 2012b). The duties of the commandant were defined as monitoring the implementation of trade development decrees, as well as supporting peaceful climbers who started selling agricultural products in urban markets.

The highlanders tried to use urban markets for the procurement of all necessary goods and it was observed by the authorities. As can be seen from the report of the control of civil part in the Stavropol province on Jan- 
uary 12, 1854 Shamil gave the Chechen and Salavian Naib 60 rubles, for the purchase through the highlanders of iron and steel.

The government tightened the requirements for registration and verification of documents, giving the right to buy and carry iron.

At the final stage of the war, when the economic component of the victory was probably dominating, the tsarist authorities decided to strengthen the economic pressure which, first of all, was expressed in the tightening of supervision over trade with the mountaineers.

In Kizlyar a civil management existed alongside with the military one since 1785. In spite of the fact that the town had an experience of management the tsarist administration was in search of the most optimal administrative organization for Dagestan in general and Kizlyar in particular during the Caucasian war.

Joining of the North Caucasus to the Russian Empire was a contradictory and complicated process involving the interlacing of numerous actors' interests, including tsarist administration and local people of different estates. Along with the military activities unfolded in the region, the Russian autocracy installed its own system of government that as the researchers fairly notice, was inevitably accompanied by absorption of local government institutes by imperial statehood.

The concentration of military and administrative power in one hands remained unchanged for the Caucasus. This axiom was reflected in the order of the central authorities that 'subordinate the city and district police to Mozdok and Kizlyar' (Trepavlov 1998: 92). Kizlyar commandants remained the main military and civilian heads of this region until the middle of the nineteenth century (Sihajok 2011: 41). In 1864, Zemstvo courts, district treasures, as well as 'Muhammedan and quarantine administration and committee for the improvement of gardening' appeared in Kizlyar (Ibid.: 97). While forming new judicial bodies the tsarist administration faced a number of urgent tasks: 'studying a regulatory role of common law, correlating adats and Sharia, gradual application of the Russian legislation in legal proceedings, problems of apprehension of new bodies by local population, the problems of estate courts and many other issues' (Ivanov 2013: 36).

Over the first half of the nineteenth century the adat and Sharia coexisted as the basis of legal proceedings and their connection was rather strong due to interchangeability. The Russian autocracy treated the highlanders' common law rather 'anxiously', perfectly understanding that it should be the basis for the legal proceeding of the new judicial institutions.

The Russian legislation demonstrated a peculiar tact in this question and it caused confidence for the new bodies. Through the activity of new judicial bodies the Russian laws came into a wide application. The application of the Russian legislation (used mostly in the sphere of criminal 
law) extended because Sharia had lost its influence. We believe that it was caused by the fact that this tool helped the Russian officials to prevent the counteraction attempts on the part of 'unpacific' highlanders.

The legal proceedings were an important component of Kizlyar commandant's power. Speaking about legal proceedings of the military period, one can note that those arrested for mutiny and support of warring highlanders would be kept in Kizlyar; the decisions on their cases were passed there as well. For example, in 1842 the residents of the Kazikumukhsky khanate joined Shamil's movement; consequently, all residents of this khanate in the town of Kizlyar were arrested. The number of prisoners was so large that colonel Shakhovsky reported to the command that 'there is no spare place in the fortress individuals in the custody' (Malakhova 2001). Under Yermolov, the Mukhtulins who captured the highlanders were exiled to Kizlyar, where they 'had to be hanged with Amalalibek' (Garunova 2009: 63). After the end of the Caucasian war and stabilization of the situation in the region, the administration performed a number of reforms in the sphere of legal proceedings. The peaceful territories of the Tersky region were divided into two districts: Vladikavkaz and Kizlyar. These territories, in turn, were divided into four districts. In all regions, representatives of autocracy tried to create a single judicial system for the entire North Caucasus. However, despite the efforts, the autocratic government could not find the optimal solution to promote the formation of a unified law and order in the region.

The key role in the development of education in and around the city also belonged to the city administration in the person of the commandant. In the first half of the nineteenth century, schools and courses were opened in the city, which demonstrate the administration's efforts to strengthen secular education to the edge of the Highlanders.

The royal administration facilitated the establishment both of secular and religious schools since they realized the importance of religion in public life. The commandant was responsible for the ensuring of all these measures and besides, he was supposed to solve not only economic and social issues of the city, but also to deal with the issues of culture and education.

In the nineteenth century, Kizlyar remained the economic and administrative-political center not on the scales of the whole Caucasus, but in the framework of Dagestan. In the nineteenth century there were positive changes in the improvement of the administrative body of the city of Kizlyar.

The system of administrative and political significance and the position of the city during the Caucasian War was reflected in the system of Ktzlyar's management. As mentioned above, Kizlyar was not a city of Dagestan, but, nevertheless, it played an important role in shaping the 
future management system in the province. The system of militarynational administration that took shape in Kizlyar was subsequently fruitfully applied in the control system of Dagestan.

The system of military and national management developed under an unstable situation in the Caucasus was a kind of political compromise and an intermediate stage in the economic, political and cultural development of the Caucasian region. The role of the commandant in the city was great. While at the end of the eighteenth century the commandant was mainly responsible for economic and political issues, the outbreak of the Caucasian war further expanded his powers. Understanding the importance of the region, the city administration tried to act as a consolidating part, as well as to resist the antagonism of the warring parties.

The imperial government used economic levers of pressure on the local population of the region to keep them under control. During the Caucasian War, representatives of the imperial administration came to the conclusion that economic dependence on the center is not enough to maintain order in the region. In the first place there is a question of cultural and intellectual rapprochement. In this context, Kizlyar's commandants played an important role in promoting the issue of cultural rapprochement and intervention.

\section{CONCLUSION}

During the long period of the commandant's work in Kizlyar, the local population started to regard Russia with more trust, while Russian authorities in their turn realized that the further relations in this region would depend on the vector of the pursued policy.

Formed in the course of the Caucasian war the institute of militarynational government was intended to ensure favourable conditions for involving the local population in the sphere of Russian legislation, and establishment of good-neighborly Russian-Caucasian relations. The system of military-national government allowed to solve in a complex a number of questions, connected with the administrative, political and economic structure of the North Caucasus.

For a long time Kizlyar was the largest city in the Caucasus with its own administrative and management system. In addition, for the nearest neighbors (Dagestan and Chechnya), it remained the main center and a significant link with the Russian authorities. During the period under review, the activities of the Kizlyar administration played a unifying role and helped the people in conflict overcome hatred and enmity, religious and other antagonisms, and understand that there is no alternative to peace and mutually beneficial cooperation.

Due to the fact that the town actively developed in all spheres, the Russian administration from the fortress foundation and till the end of 
the nineteenth century was forced to improve and change the system of government of the town, to introduce new positions, and to control and regulate their activity.

The solution of social and economic problems, work in cultural and educational spheres as well as involvement of the local population into the Russian legal space were the paramount tasks which the commandants of the fortress faced until the mid-nineteenth century. During this period the commandants performed their duties with respect to all spheres of activity of the city. Meanwhile, the economic and sociocultural aspects of the commandant's activity became of utmost importance for the promotion of geopolitical interests of the Russian Empire.

\section{REFERENCES}

Butkov, P. G. 1869. Materials for a Modern History of the Caucasus from 1722 to 1803.Collected Works.3 vols. St.-Petersburg. URL: http: //www.vostlit.narod.ru/Texts/Dokumenty/S.Kavkaz/Butkov1/text4.htm. In Russian (Бутков, П. Г. Материаль для новой истории Кавказа с 1722 nо 1803 год / соч. П. Г. Буткова. 3 т. СПб.)

Chekulayev, N. D. 2008. The Russian Troops in Daghestan in the Context of the Caucasian Policy of Russia (1722-1735): Problems of the Caucasian Policy in the Region. Makhachkala: DNTs RAN, Institute of History, Archeology and Ethnography. URL: http:www.dissercat.com/content/rossioskievoiska-v-dagestane-v-1722-1735gg-problemy-kavkazskoi-politiki-v-regione. In Russian (Чекулаев, Н. Д. Российские войска в Дагестане в контексте Кавказской политики России (1722-1735) Проблемы кавказской политики в регионе. Махачкала: ДНЦ РАН, Институт истории, археологии и этнографии).

Gadzhiev, M. G., Davudov, O. M., and Shikhsaidov, A. R. 1996. History of Dagestan since the Most Ancient Times until the End of the $15^{\text {th }}$ Century to Our Days. Makhachkala: Institute of History, Archeology and Ethnography. In Russian (Гаджиев, М. Г., Давудов, О. М., Шихсаидов, А. Р. История Дагестана с древнейших времен до конца $X V$ в. Махачкала: Институт истории, археологии и этнографии).

Gadzhiev, V. G. et al. (eds.) 1988.The Russian-Daghestan Relations in the $18^{\text {th }}$ - the Beginning of the $19^{\text {th }}$ Century. Moscow: Nauka. In Russian (Гаджиев, В. Г. и др. (сост.) Русско-дагестанские отношения в XVIII начале XIX в. М.: Наука).

Garunova, N. N. 1999. Kizlyar in the $18^{\text {th }}-$ the First Half of the $19^{\text {th }}$ Century: Problems of Political, Social, Economic and Cultural Development. Author's thesis of Candidate of Historical Sciences. Makhachkala. URL: http://www.dissercat.com/content/kizlyar-v-xviii-pervoi-polovine-xix-vekaproblemy-politicheskogo-sotcialno-ekonomicheskogo-i. In Russian (Гарунова, Н. Н. Кизляр в XVIII - первой половине XIX века: проблемь 
политического, социального, экономического и культурного развития. Автореф. дис. ... канд. ист. наук. Махачкала).

Garunova, N. N. 2009. Sketches of History of Winemaking and Cognac Production in Kizlyarshshina in the $18^{\text {th }}-21^{\text {st }}$ Centuries. Makhachkala. In Russian (Гарунова, Н. Н. Очерки истории виноделия и коньячного производства в Кизляршиине в XVIII-XXI вв. Махачкала).

Ivanov, A. G. (Ed.) 2013. Paradigms and Estimates of the Caucasian Policy of Russia in the Past and the Present. Krasnodar: Kuban State University. In Russian (Парадигмы и оченки Кавказской политики России в прошлом и настоящем / Ред. А. Г. Иванов. Краснодар: Кубанский государственный университет).

Malakhova, G. I. 2001. Development of the Russian Public Administration in the North Caucasus at the End of the $18-19^{\text {th }}$ Centuries. Doctoral Thesis. Moscow. In Russian (Малахова, Г. И. Становление Российского государственного управления на Северном Кавказе в коние VIII-XIX вв. Диссертация на соискание ученой степени доктора исторических наук. Москва.)

People's Liberation... 2005.People's Liberation Fight of Dagestan and Chechnya under the Leadership of Imam Shamil. Collection of documents. M.: Ekho Kavkaza. In Russian (Народно-освободительная борьба Дагестана и Чечни под руководством Имама Шамиля. Сборник документов. М.: Эхо Кавказа).

Serdyuk, A. V. 2015. Judicial Reform of 1864: Features of Realization in the North Caucasus (the Second Half of the $19^{\text {th }}$ - the Beginning of the $20^{\text {th }}$ Centuries). Author's thesis of Candidate of Juridical Sciences. Moscow. In Russian (Сердюк, А. В. Судебная реформа 1864 года: особенности реализаџии на Северном Кавказе (вторая половина ХІХ начало $X X$ в. Автореф. дис. ... канд. юрид. наук. Москва).

Sikhadzhok, Z. R. 2011. Legal Status of the Caucasian Deputy in the Legislation of the Russian Empire, 1845-1915. Author's thesis of Candidate of Juridical Sciences. Krasnodar. In Russian (Сихаджок, 3. Р. Правовой статус кавказского наместника в законодательстве Российской империи, 1845-1915 г2. Автореф. дис. ... канд. юрид. наук. Краснодар).

The Report of the Control of Civil Part in the Stavropol Province Trustee over the Peaceful Mountaineers in Kizlyar Banning the Sale of Iron and Steel Mountaineers. URL: http://www.vostlit.info/Texts/Dokumenty/Kavkaz/XIX/ 1800-1820/Dvizenie/381-400/390.htm. In Russian (Pапорт управляющего гражданской частью в Ставропольской губернии попечителю над мирными гориами в Кизляре о запрещении продажи гориам железа и стали. 12 января 1854).

Trepalov, V. V. 1998. A Problem of Non-Slavic Statehood in the Russian History: Factor of Military Victories and Defeats. Caucasian War: Con- 
troversial Issues, New Approaches. Abstracts of the International Scientific Conference. Makhachkala. In Russian (Трепалов, В. В. Проблема неславянской государственности в российской истории: фактор военных побед и поражений. Кавказская война: спорные вопросы, новые подхо$\partial b l$. Тезисы докладов междунар. науч. конференции. Махачкала).

Velikaya, E. V. 2012a. Great Events of the Russian Government on Trade Development in the North-East Caucasus in the First Half of the $19^{\text {th }}$ Century. Istoricheskie, filosofskie, politicheskie i yuridicheskienauki, kulturologiyaiiskusstvovedenie. Voprosy teorii i praktiki 9 (23): 47-50. In 2 parts. Part 1. In Russian (Великая, Е. В. Мероприятия Российского правительства по развитию торговли на Северо-Восточном Кавказе в первой половине XIX в. Исторические, философские, политические и юридические науки, культурология и искусствоведение. Bопросы теории и практики 9 (23): 47-50. В 2-х ч. Ч. 1).

Velikaya, E. V. 2012b. Evolution of Trade Relations in the North-East Caucasus in the First Half of the Nineteenth Century. Regional Social and Humanitarian Studies. History and Modernity. Materials of the International Scientific and Practical Conference, January 25-26. Penza - Prague Semey: Nauchno-izdatel'skiy tsentr 'Sotsiosfera'. URL: http://sociosphera. com/publication/conference/2012/158/evolyuciya_torgovyh_otnoshenij_na_s everovostochnom_kavkaze_v_pervoj_polovine_xix_veka/. In Russian (Великая, Е. В. Эволюция торговых отношений на Северо-Восточном Кавказе в первой половине ХІХв. Региональныле социиогуманитарные исследования. История и современность. Материалы международной научно-практической конференции 25-26 января 2012 г. Пенза - Прага - Семей: Научно-издательский центр «Социосфера»). 